\title{
SHADE TOLERANCE OF MARIGOLD PLANTS (Calendula officinalis)
}

\section{TOLERANCIA A LA SOMBRA EN PLANTAS DE CALÉNDULA (Calendula officinalis)}

\author{
Fánor Casierra-Posada ${ }^{1 *}$, Omar F. Ávila-León ${ }^{2}$ \\ ${ }^{1}$ Agronomist, PhD. Pedagogical and Technological University of Colombia (UPTC), Faculty of Agricultural Sciences, Plant \\ Ecophysiology research Group. Avenida Central del Norte No. 39-115, Tunja, Colombia. *Corresponding author: fanor. \\ casierra@uptc.edu.co; ${ }^{2}$ Agronomist. Talex s.a.s., Kra 6A No. 11-36, Duitama, Colombia, e-mail: omarfercho_5@yahoo.es
}

Rev. U.D.C.A Act. \& Div. Cient. 18(1): 119-126, Enero-Junio, 2015

\section{SUMMARY}

Pot marigold (Calendula officinalis L.) is the second most commonly-sold medicinal herb in Colombia. The study was performed in Tunja, Colombia, in which chlorophyll and carotenoid content were evaluated in pot marigold grown under low and high light conditions (35\% and $100 \%$ of full daylight). Chlorophyll fluorescence parameters and electron transport rate were also evaluated. Compared to full sun plants, shaded plants had a higher ratio of chlorophyll a to chlorophyll $b$, and a lower ratio of carotenoids to chlorophyll. Values for maximum fluorescence $\left(F_{m}\right)$, variable fluorescence $\left(F_{v}\right)$, and maximum quantum efficiency of photosystem II (the ratio $F_{v} / F_{m}$ ) increased in shaded plants, while electron transport rate was reduced. These results suggest that pot marigold plants are very sensitive to low-light conditions.

Key words: Chlorophyll, carotene, stress, $F_{v} / F_{m}$, electron transport rate, light reduction.

\section{RESUMEN}

La caléndula (Calendula officinalis L.) es la segunda planta medicinal más comercializada en Colombia. El estudio, se realizó en Tunja, Colombia, en el que se evaluaron los contenidos de clorofila y de carotenoides en plantas de caléndula, expuestas a condiciones de plena iluminación solar y sombra, bajo una malla de fibra sintética, que reduce la luz en un $35 \%$. También se evaluaron los parámetros de fluorescencia de la clorofila y la tasa de transporte de electrones. En comparación con las plantas a pleno sol, las plantas sombreadas presentaron una mayor proporción de clorofila $a / b$ y una proporción inferior de carotenoides/clorofila. Los valores de fluorescencia máxima $\left(F_{m}\right)$, la fluorescencia variable $\left(F_{v}\right)$ y la eficiencia cuántica máxima del fotosistema II (la relación $F_{v} /$ $F_{m}$ ) aumentaron en las plantas bajo sombra, mientras que la tasa de transporte de electrones, se redujo. Estos resultados sugieren que las plantas de caléndula son muy sensibles a las condiciones de poca luz.

Palabras clave: Clorofilas, carotenos, estrés, $F_{v} / F_{m}$, tasa de transporte de electrones, reducción de la luz.

\section{INTRODUCTION}

It appears that Calendula is a genus native to the Macaronesian and Mediterranean regions, perhaps originating in Egypt, being widely grown as an ornamental plant and naturalized elsewhere (Patrick et al. 1996; Paolini et al. 2010). Due to the complex composition and natural variability of various compounds in herbal products, different methods has been used to develop a profile of the different constituents within herbal products (Agatonovic-Kustrin \& Loescher, 2013). On the other hand, Paolini et al. (2010) recognized relationships between concentrations of volatile samples and both the geographical origins of samples and the seasonal variation (winter vs. spring), specially related to oil composition in Calendula arvensis.

Calendula officinalis, also known as Pot Marigold, is part of the Asteraceae/Compositae botanical family (Jellin et al. 2003). The volume of pot marigold commercialized in Colombia is second only to artichoke among medicinal plants and is used by $72 \%$ of the country's laboratories that process aromatic plants (Duque, 2001). The same author mentions that multiple medicinal properties are attributed to C. officinalis, such as anti-inflamatory, antiseptic, sudorific, and wound-healing characteristics, as well as the relief of stomach ulcers. Despite its importance for the pharmaceutical industry, there has relatively little research been carried out relating to the physiology of these plants, although it is well known that changes in irradiance impact on 
plant growth, as well as on various aspects of physiology and cellular biochemistry of plants. In addition, shade tolerance is considered an important factor in community dynamics of photosynthetic organisms. The success or failure of habitat selection by plants is determined in large part by their ability to tolerate shade (Naumburg \& Ellsworth, 2000).

There are two types of plant response to shade(Vandenbussche et al. 2005). One response is shade acclimation, which refers to a reduction of the ratio of chlorophyll $a$ to chlorophyll $b$, or to anatomical modifications in the plant such as an increase in specific leaf area (Evans \& Poorter, 2001). The other type of response is shade avoidance, by which plants maximize light capture by distancing their leaves from the shade (Ballaré, 1999). Shade-avoiding plants possess a mechanism that responds rapidly to changes in the red/far red relationship, gauged by the phytochrome group of pigments (Franklin \& Whitelam, 2005). The analysis of chlorophyll a fluorescence makes it possible to characterize the effects and modes of action of different types of environmental stress on all plants types and it has been routinely measured for the analysis of photosynthesis and environmental changes (Gonzalez et al. 2008; Guo et al. 2015). The most often used ratios in chlorophyll fluorescence from photosystem II are the quotients $F_{v} / F_{m}$ and $F_{v} / F_{0}$, which indicate the potential quantum efficiency of PSII (Hartmut et al. 2004). An example is the work of Sarijeva et al. (2007) and Pompelli et al. (2010), who found that the value of the quotient $F_{v} / F_{0}$ was more sensitive than $F_{v} / F_{m}$ and showed higher values in plants grown in full sun as compared to shade-grown plants.

Light intensity has been found to cause changes in the content of secondary metabolites in medicinal plants. In Glycyrrhiza uralensis, the content of glycyrrhizic acid and liquiritin increased under shade (Hou et al. 2010). Both spectrum and light intensity can stimulate the production of secondary metabolites in medicinal plants grown under low light, such as methylxanthines in Ilex paraguariensis (Coelho et al. 2007), alkaloids in Delphinium barbey (Ralphs et al. 1998) and aloin (barbaloin) in Aloe mutabilis (ChauserVolfson \& Gutterman, 1998).

The objective of the present study was therefore to determine the shade tolerance in plants of $C$. officinalis, through the measurement of chlorophyll a fluorescence and the variation of photosynthetic pigment content.

\section{MATERIALS AND METHODS}

Marigold seeds were sown in peat plugs in germination trays. Plantlets were transplanted to $2 \mathrm{~kg}$ plastic bags filled with standard soil (Andosol - Fao Taxonomy), five weeks after emergence. Plants were grown under two treatments, (full sunlight and 35\% shading), with three replications of three plants each, for a total of 18 plants in the experiment. The number of taken samples for analysis was considered sufficient, since the standard deviation of the results was within acceptable values, finding little variation between the averages. Shading was accomplished by using one layer of commercial black shade cloth (Plastempack, Bogotá, Colombia) from 20 days after transplanting to the end of the study. Each day air temperatures of the two treatments were recorded hourly from 6:00 to $18: 00 \mathrm{~h}$, during 12 days. Irrigation was provided manually every three days as needed. The global solar radiation during the study period was recorded at a nearby meteorological station, at $80 \mathrm{~m}$ distance from the experiment site, and fluctuated between 294.68 and 593.60 gram calories $\mathrm{cm}^{-2}$. It should be noted that ambient light conditions in Tunja, Colombia, where the experiment was carried out are naturally low due to the almost-constant presence of clouds.

To determine chlorophyll content, five fully-developed leaves per replication were taken randomly and mixed for extraction. Samples were taken hourly from 6:00 to 18:00 h (13 samples per day) during four sunny days. Chlorophyll $(a+b)$ and carotenoid pigments were determined spectrophotometrically by a Milton Roy Spectronic 401 spectrometer (Milton Roy, Ivyland, PA, USA), and were expressed as $\mathrm{mg} \mathrm{g}^{-1}$ (fresh matter), according to Lichtenthaler \& Wellburn (1983). Besides the chlorophyll and carotenoid contents in leaves, the chlorophyll $a$ / chlorophyll $b$ and the carotenoid / chlorophyll ratios were calculated.

Chlorophyll fluorescence was measured with a Junior-PAM fluorometer (Walz, Effeltrich, Germany) with a pulse amplitude modulation of $820 \mu \mathrm{mol} \mathrm{m}^{-2} \mathrm{~s}^{-1}$. Leaves were dark-adapted for approximately $30 \mathrm{~min}$ prior to measurements. Measured fluorescence coefficients were maximum fluorescence $\left(F_{m}\right)$, variable fluorescence $\left(F_{v}\right.$, maximum photochemical quantum yield of PS II $\left(F_{v} / F_{m}\right)$, and relative electron transport rate (ETR). Samples were exposed to increasing intensities of actinic illumination (0 to $\left.820 \mu \mathrm{mol} \mathrm{m}^{-2} \mathrm{~s}^{-1}\right)$ to determine the PS II electron transport rate at increasing light intensity.

The experiment was a completely randomized design, replicated three times. The treatments were two light environments (sun and shade). For chlorophyll fluorescence measurements, three leaves from each replication were taken for measurements $(n=9)$. Leaves for measuring chlorophyll fluorescence and electron transport rate were taken at 13:00 h. Significance at $p<0.05$ was assessed by ANOVA and the means compared by Tukey's HSD Post-hoc test using IBM SPSS Statistics version 19.0.0 (IBM, N.Y., USA). 


\section{RESULTS AND DISCUSSION}

Light intensity and temperature: average air temperature in the experiment into full sunlight and under the black cloth netting were 20.4 and $19.2^{\circ} \mathrm{C}$, respectively. The mean value of the photosynthetic photon flux (PPF) measured at plant

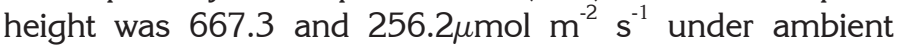
natural light and under the black cloth, respectively. The temperature difference was not sufficiently large to cause statistical differences in the results, but the difference in photon flux density was large enough to cause significant differences, as there was a $38.3 \%$ reduction under the black cloth (Figure 1).
Kim et al. (2011) found no large difference between maximum and minimum leaf temperature in Vaccinium corymbosum when shade cloths excluding $31,60,73$, and $83 \%$ of light from plants were used. These authors mention that the temperature difference was $2^{\circ} \mathrm{C}$ between the treatments. Nevertheless, Zhang et al. (2003) reported that in plants of Paeonia suffruticosa exposed to different light levels, leaves exposed to low light registered higher temperatures than unshaded or partially-shaded plants, because they had no way of regulating temperature through increased transpiration. Campoy et al. (2010) found air temperature differences greater than $5^{\circ} \mathrm{C}$ in Prunus armeniaca plants exposed to full sun and about $20 \%$ of full ambient light. The

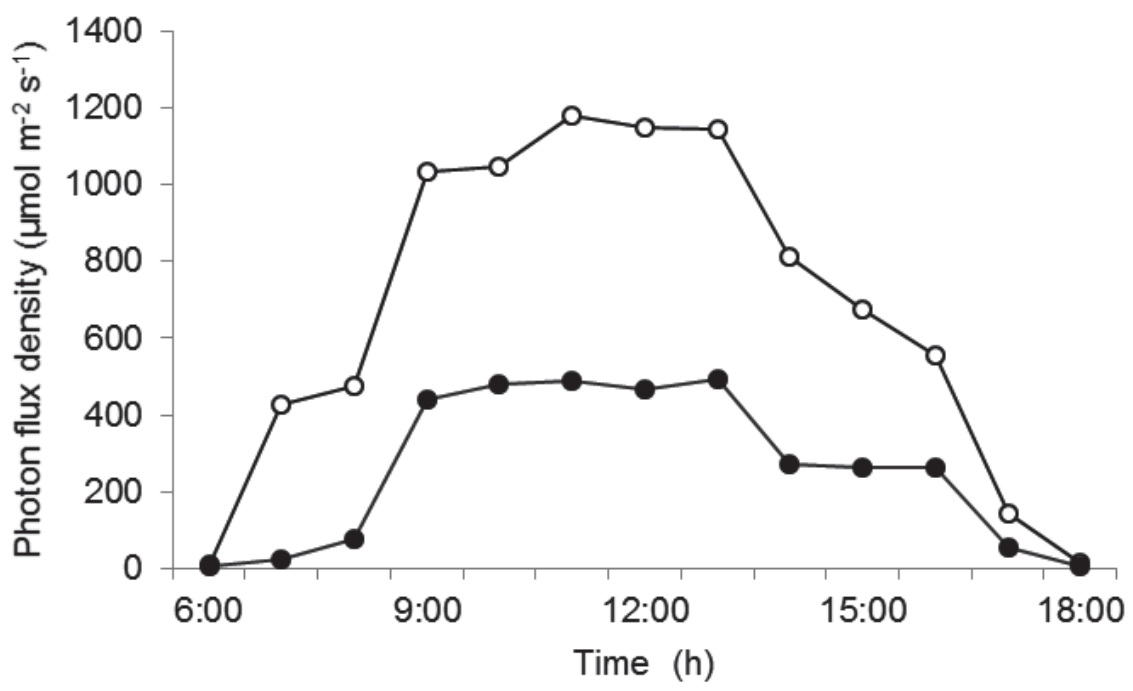

Figure 1. Curves of the average diurnal variation in photon flux density registered in Tunja, Colombia under full sunlight (open circles) and $35 \%$ shade cloth (solid circles), during the course of the experiment.

differences we found may be due to the fact that the cited studies were conducted in temperate zones, where summer conditions can create widely differing temperatures between sun and shade. In contrast, the present study was conducted at high altitude in an equatorial zone that experiences no appreciable rise in temperature during the dry season. It should clarify that the study region has a bimodal rainfall regime and therefore could not compare to the seasonality that occurs in the temperate zone. Average temperature in Tunja is a relatively low and constant $12^{\circ} \mathrm{C}$ year-round, meaning that average conditions do not provide for large temperature differences between sun and shade.

In terms of radiation under full sun and shaded conditions, the results of our study differ from many studies conducted in temperate or subtropical zones in relatively cloudless conditions, which report photosynthetic photon flux values around $2000 \mu \mathrm{mol} \mathrm{m}^{-2} \mathrm{~s}^{-1}$ (Dai et al. 2009; Senevirathna et al. 2003). Zhang et al. (2003) mention illumination conditions analogous to those of the present study which induced similar results in relation to the values of the parameters for determining the chlorophyll fluorescence.

Pigments content: In terms of pigment content, there were no statistically significant differences found for chlorophyll $a$, chlorophyll $b$, or total carotenoids. However, differences were detected for the ratios chlorophyll a/chlorophyll $b$ and carotenoids/chlorophyll. In shaded plants chlorophyll $a$ /chlorophyll $b$ ratio increase by $8.41 \%$ with respect to full-sun plants, and carotenoids/chlorophyll was reduced 
by $5.45 \%$ (Table 1). Carotenoids other than xanthophylls, e.g. $\beta$-carotene, are related to photoprotective processes, therefore their measurement is an effective index to determine changes in photosynthetic light-use efficiency in response to stress on a long-term level (Filella et al. 2009).
The ratio of $\mathrm{Chl} a / \mathrm{Chl} b$, among other indices, has been considered a key factor for classifying plants in terms of their shade tolerance (Dai et al. 2009); individuals of tolerant shade adapted plant species present a low value for this ratio compared to individuals exposed to high light. This is due

Table 1. Photosynthetic pigment ratios in marigold leaves (Calendula officinalis L.) exposed to different light-environments $(n=156)$.

\begin{tabular}{|c|c|c|}
\cline { 2 - 3 } \multicolumn{1}{c|}{} & Chlorophyll a / Chlorophyll b ratio & Carotenoid / Chlorophyll (a+b) ratio \\
\hline Sun & $1.07 \quad \pm 0.14 \mathrm{~b}$ & $1.65 \quad \pm 0.25 \mathrm{a}$ \\
\hline Shade & $1.16 \pm 0.14 \mathrm{a}$ & $1.56 \quad \pm 0.24 \mathrm{~b}$ \\
\hline
\end{tabular}

Different letters within columns show significant difference between treatments based on the Tukey's HSD Post-hoc test at $(\mathrm{p}<0.05)$.

to a higher concentration of chlorophyll $b$ in shade-adapted plants of shade-tolerant species. Increases in $\mathrm{Chl} b$ content are most likely due to changes in the organization of both light harvesting and electron transport components (Yamazaki et al. 2005; Dai et al. 2009). A commonly accepted hypothesis is that under conditions of low light, the relation of chlorophyll $a /$ chlorophyll $b$ is reduced (Vandenbussche et al. 2005) with the purpose of improving efficiency in the absorption of radiation from the blue-light range of the spectrum (Yamazaki et al. 2005). However, the opposite occurred in the present study (Table 1). A similar finding of this study was reported by Beneragama \& Goto (2010).

There are abundant reports of a low ratio of chlorophyll a/ chlorophyll $b$ in response to shading (Dai et al. 2009), and few that mention an unchanging value for this ratio under differing light regimes (Murchie \& Horton, 1998). Nevertheless, Beneragama \& Goto (2010) propose that a low ratio of chlorophyll $a /$ chlorophyll $b$ is inherent to certain species. Thus in the present study the low ratio of chlorophyll $a /$ chlorophyll $b$ found in shaded plants may be an inherent trait of pot marigold, or it may indicate a lack of shade tolerance in the species.
Regarding to the carotenoids / chlorophyll ratio, the results of the present study agree with the findings of Sarijeva et al. (2007), who found in leaves of full-sun-grown Ginkgo biloba a higher carotenoid content than total chlorophyll, and carotenoid contents under full-sun grown plant leaves were double than those found in shade-grown leaves. In addition, Rosevear et al. (2001) reported that the content of photoprotective compounds such as $\beta$-carotene and the components of the xanthophyll cycle was reduced considerably in conditions of low light. These differences in the ratio of carotenoids to chlorophyll are the result of leaf adaptation to light conditions, since leaves accustomed to intense light and those accustomed to shade present differences in the number of light-harvesting complexes and the number of reaction centers (Lichtenthaler et al. 2007).

Chlorophyll fluorescence: No difference was found in the values of $F_{0}$ for plants in the two treatments. Differences in chlorophyll fluorescence parameters between fully developed sun and shade-grown leaves of pot marigold are shown in table 2. While $F_{m}, F_{v}$ and $F_{v} / F_{m}$ increased under shade, the value of ETR increased in leaves grown in full sunlight.

Table 2. Differences in maximum and variable fluorescence, maximum photochemical quantum yield of PS II, and relative electron transport rate in marigold leaves (Calendula officinalis L.) exposed to different light-environments growing in the tropical highlands.

\begin{tabular}{|c|c|c|c|c|c|}
\cline { 2 - 7 } \multicolumn{1}{c|}{} & \multicolumn{2}{|c|}{$\mathrm{Fm}_{\mathrm{m}}$} & \multicolumn{2}{c|}{$\mathrm{Fv}_{\mathrm{v}}$} & \multicolumn{2}{c|}{$\mathrm{Fv}_{\mathrm{Fm}}$} & \multicolumn{2}{c|}{ ETR } \\
\hline Sun & $661.7 \pm 71.7 \mathrm{~b}$ & 520.5 & $\pm 49.8 \mathrm{~b}$ & $0.78 \pm 0.01 \mathrm{~b}$ & $99.2 \pm 14.0 \mathrm{a}$ \\
\hline Shade & 879.6 & $\pm 124.5 \mathrm{a}$ & $712.2 \pm 92.2 \mathrm{a}$ & $0.81 \pm 0.02 \mathrm{a}$ & $82.0 \pm 13.9 \mathrm{~b}$ \\
\hline
\end{tabular}

Different letters within same column show significant difference between treatments based on Tukey's HSD Posthoc test at $\mathrm{p}<0.05(\mathrm{n}=9)$. 
The lack of significant difference in the value of $F_{0}$ is considered evidence of the stability of photosynthetic machinery in pot marigold plants. The low value of $F_{m}$ in plants grown under full sun conditions as compared to shade-grown plants can be attributed to a higher level of quenching capacity in the former ones. Nevertheless, this is not a trait common to all plants; Gonçalves et al. (2001) found that the value of $F_{m}$ in Swietenia macrophylla was lower in shade-grown plants than in those grown under full sun, while in Dipteryx odorata the opposite occurred, which suggests that heat quenching capacity was less important in S. macrophylla than in D. odorata.

The value of $F_{\mathrm{v}}$ represents the difference between $F_{m}$ and $F_{0}$, and as there were no significant differences for $F_{0}$, it is expected that the difference in values of $F_{v}$ would be roughly equivalent to those for $F_{m}$. The lower value of $F_{V}$ in plants grown under full sun is a common result, because sun-exposed plants have thick leaves with lower leaf area as compared to shadegrown leaves (Kim et al. 2011). The thinner leaves caused by conditions of low light are possibly due to a reduction in the number and size of mesophyll cells (Peri et al. 2007). Under these conditions, according to Hartmut et al. (2004), chlorophyll fluorescence overlaps the in vivo absorption band of chlorophyll $a$ and is thus reabsorbed in protein pigments of the thylakoids. This reabsorption would be greater in thick, sun-exposed leaves than in thin, shade-grown leaves.

Maximum photochemical efficiency of PSII, represented by the ratio $F_{\mathrm{v}} / F_{m}$, corresponded to the normal range in both treatments, as values for this parameter from 0.78 to 0.85 are associated with healthy, unstressed plants (Percival,
2004; Demmig-Adams \& Adams, 2006). Nevertheless, the comparison of this ratio between the two treatments shows a slightly, though statistically significant, lower value for full sun plants, which implies that full sun exposure leads to some degree of plant stress, possibly caused by the higher incidence of UV radiation (Casierra-Posada, 2007). In addition it must be noted that fluorescence were measured at 13:00 h, when the noontime radiation is strong, as seen in figure 1 . Also, the average UV index in the study zone is 13.6 (extremely high) (IDEAM, 2011), which is one more factor to explain the reduction in $F_{v} / F_{m}$ in plants exposed to full sun, due to the $F_{v} / F m$ ratio is often used as an indicator of the degree of photoinhibition in PSII (Pompelli et al. 2010; DemmigAdams \& Adams, 2006). Given that the ratio of carotenoids/ chlorophyll was higher in plant leaves grown under full sun, it can be interpreted that under these conditions the photoprotection mechanism was triggered in the form of increased carotenoid content.

ETR value represents the relative quantity of electrons passing through PSII during the steady state of photosynthesis (Tezara et al. 2003). Under shaded conditions, ETR was reduced an average of $17.33 \%$ as compared to fully-illuminated plants, with statistically significant differences $(p<0.05)$ (Table 2$)$. This difference can be observed in the curves of electron transport through PSII, calculated with increasing light intensity (Figure 2).

Antenna complexes are formed by many chlorophyll molecules, and PSII is especially rich in chlorophyll $b$ molecules (Ramanan et al. 2015). Given that in the present

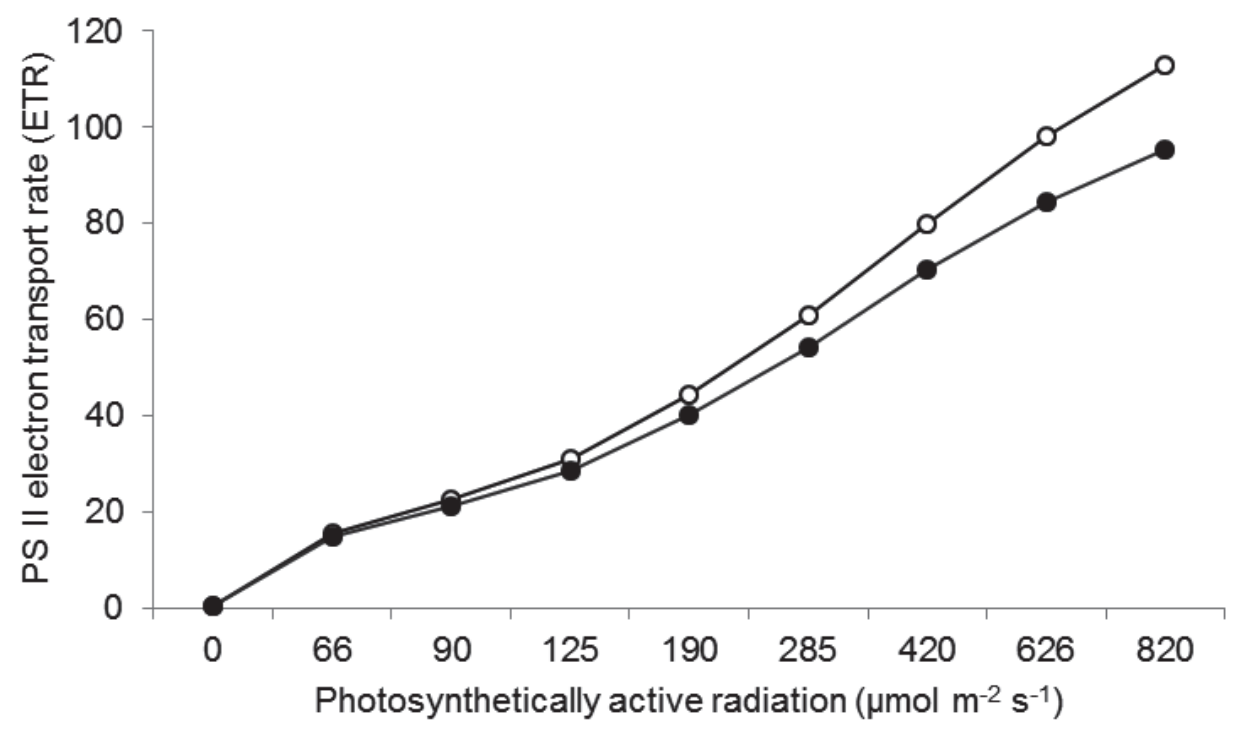

Figure 2. Electron transport rate measured on pot marigold plants (Calendula officinalis L.) exposed to shade (solid circles) or full sunlight (open circles) $(\mathrm{p}<0.05 ; \mathrm{n}=9)$. 
study it was found that shade-grown plants showed a high ratio of chlorophyll a/chlorophyll $b$, a lower content of chlorophyll $b$ than chlorophyll a can be inferred. This fact induced a reduction in electron transport rate of PSII as a result of low light and a reduction in chlorophyll $b$ content in shade-exposed plants as compared to full sun plants. Similar to the findings of Chen \& Xu (2006), the magnitude of electron transport rate in low-light conditions depends on incident radiation and antenna size. Thus the reduction in antenna size due to lower pigment content, chlorophyll $b$, in this case, would have as consequence a reduction in electron transport.

Based on the results, we can infer that pot marigold plants exhibited little adaptation to shaded conditions, evidenced by the lack of difference in total chlorophyll content between full sun and shaded treatments. Such a result is unusual because normally shade-grown plants increase total chlorophyll content in order to capture a higher number of photons, though it is possible that given the generally low ambient radiation in Tunja, even under full-sun conditions, plant response to artificial shading was muted. Another common response in plants grown in low-light conditions is a low value for the ratio chlorophyll $a /$ chlorophyll $b$, which is an indication of shade acclimation (Dai et al. 2009). A reduced value in this ratio in plants grown under reduced light is a key factor for identifying their capacity to tolerate shade, since species tolerant to shade have a higher concentration of chlorophyll $b$ in relation to chlorophyll $a$. However, instead of a reduction in this ratio, shaded plants in the present study showed an increase. This higher chlorophyll $a$ / chlorophyll $b$ ratio, along with their inability to increase total chlorophyll content, led to a reduction in electron transport in shade-grown plants. On the other hand, full-sun pot marigold plants did show an increase in carotenoid/chlorophyll ratios as compared to shaded plants, as well as a lower efficiency of PSII. Both results point to a pigment-based physiological mechanism to protect plants from UV radiation, which is high in the highland equatorial zone of the experiment.

Acknowledgments: The team gratefully acknowledges the generous support of the Research Directorate (Dirección de Investigaciones - DIN) of the Pedagogical and Technological University of Colombia (UPTC) for providing us with the funding and opportunity to conduct this research project. We also gratefully acknowledge matching support from the members of the Research Group in Plant Ecophysiology (Grupo Ecofisiología Vegetal) of the Faculty of Crop and Animal Sciences of the UPTC. Funding: This study was supported by the Directorate of Research (Dirección de Investigaciones - DIN) of the Pedagogical and Technological University of Colombia (UPTC). It followed the working priorities of the Plant Ecophysiology Research Group, part of the Agricultural Engineering Program of the Faculty of Crop and Animal Sciences of the UPTC. Conflict of interests: The manuscript was prepared and reviewed with the participation of the authors, who declare that there exists no conflict of interest that puts in risk the validity of the results presented.

\section{BIBLIOGRAPHY}

1. AGATONOVIC-KUSTRIN, S.; LOESCHER, C.M. 2013. Qualitative and quantitative high performance thin layer chromatography analysis of Calendula officinalis using high resolution plate imaging and artificial neural network data modelling. Anal Chim. Acta 798:103-108.

2. BALLARÉ, C.L. 1999. Keeping up with the neighbors: phytochrome sensing and other signaling mechanisms. Trends Plant Sci. 4:97-102.

3. BENERAGAMA, C.K.; GOTO, K. 2010. Chlorophyll $a: b$ ratio increases under low-light in 'shade-tolerant' Euglena gracilis. Trop. Agr. Res. 22(1):12-25.

4. CASIERRA-POSADA, F. 2007. Fotoinhibición: Respuesta fisiológica de los vegetales al estrés por exceso de luz. Rev. Col. Cienc. Hort. 1(1):114-123.

5. CAMPOY, J.A.; RUIZ, D.; EGEA, J. 2010. Effects of shading and thidiazuron + oil treatment on dormancy breaking, blooming and fruit set in apricot in a warmwinter climate. Sci Hortic-Amsterdam. 125:203-210.

6. CHAUSER-VOLFSON, E.; GUTTERMAN, Y. 1998. Content and distribution of anthrone $\mathrm{C}$-glycosides in the South African arid plant species Aloe mutabilis growing in the direct sunlight and the shade in the Negev Desert of Israel. J. Arid Environ. 40:441-451.

7. CHEN, Y.; XU, D-Q. 2006. Two patterns of leaf photosynthetic response to irradiance transition from saturating to limiting one in some plant species. New Phytol. 169:789-798.

8. COELHO, G.C.; RACHWAL, M.F.G.; DEDECEK, R.A.; CURCIO, G.R.; NIETSCHE, K.; SCHENKEL, E.P. 2007. Effect of light intensity on methylxanthine contents of Ilex paraguariensis A. St. Hil. Biochem. System. Ecol. 35(2):75-80.

9. DAI, Y.; SHEN, Z.; LIU, Y.; WANG, L.; HANNAWAY, D.; LU, H. 2009. Effects of shade treatments on the photosynthetic capacity, chlorophyll fluorescence, and chlorophyll content of Tetrastigma hemsleyanum Diels et Gilg. Environ. Exp. Bot. 65:177-182. 
10. DEMMIG-ADAMS, B.; ADAMS, W.W. 2006. Photoprotection in an ecological context: the remarkable complexity of thermal energy dissipation. New Phytol. 172(1):11-21.

11. DUQUE, A. 2001. Encuesta nacional de plantas medicinales y aromáticas una aproximación al mercado de las PMyA en Colombia. Instituto de Investigación de Recursos Biológicos Alexander von Humboldt. Biocomercio Sostenible. Available online at: $\quad$ http://farmacia.udea.edu.co/ ff/Comercio.pdf (accessed 01/12/2013).

12. EVANS, J.R.; POORTER, H. 2001. Photosynthetic acclimation of plants to growth irradiance: the relative importance of specific leaf area and nitrogen partitioning in maximizing carbon gain. Plant Cell Environ. 24:755-767.

13. FILELLA, I.; PORCAR-CASTELL, A.; MUNNE-BOSCH, S.; BACK, J.; GARBULSKY, M.F.; PENUELAS, J. 2009. PRI assessment of long-term changes in carotenoids/chlorophyll ratio and short-term changes in de-epoxidation state of the xanthophyll cycle. Int. J. Remote Sens. 30(17):4443-4455.

14. FRANKLIN, K.A.; WHITELAM, G.C. 2005. Phytochromes and shade avoidance responses in plants. Ann. BotLondon. 96:169-175.

15. GUO, Y.; ZHOU, Y.; TAN, J. 2015. Wavelet analysis of pulse-amplitude-modulated chlorophyll fluorescence for differentiation of plant samples. J. Theor. Biol. 370:116-120.

16. GONÇALVES, J.F.D.C.; MARENCO, R.A.; VIEIRA, G. 2001. Concentration of photosynthetic pigments and chlorophyll fluorescence of mahogany and tonka bean under two light environments. Rev. Bras. Fisiol. Veg. 13(2):149-157.

17. GONZALEZ, A.; MARTIN, I.; AYERBE, L. 2008. Yield and osmotic adjustment capacity of barley under terminal water-stress conditions. J. Agron. Crop. Sci. 194:81-91.

18. HARTMUT, K.; LICHTENTHALER, H.K.; BABANI, F. 2004. Light adaptation and senescence of the photosynthetic apparatus. Changes in pigment composition, chlorophyll fluorescence parameters and photosynthetic activity. In: Papageorgiou, G.C.; Govindjee. (eds). Chlorophyll fluorescence: a signature of photosynthesis. Dordrecht: Springer; p.713-736.
19. HOU, J-L.; LI, W-D.; ZHENG, Q-Y.; WANG, W-Q.; XIAO, B.; XING, D. 2010. Effect of low light intensity on growth and accumulation of secondary metabolites in roots of Glycyrrhiza uralensis Fisch. Biochem. Syst. Ecol. 38:160-168.

20. IDEAM. 2011. Indice UV para Tunja. Available online at: http://bart.ideam.gov.co/wrfideam/indiceuv/indice. php?ciudad =TUNJA(accessed 01/12/2011).

21. JELLIN, J.M.; GREGORY, P.J.; BATZ, F.; HITCHENS, K. 2003. Pharmacist's Letter/Prescriber's Letter Natural Medicines Comprehensive Database, 5th ed. Stockton, CA, p.265-66.

22. KIM, S.J.; YU, D.J.; KIM, T-C.; LEE, H.J. 2011. Growth and photosynthetic characteristics of blueberry (Vaccinium corymbosum cv. Bluecrop) under various shade levels. Sci. Hortic-Amsterdam. 129:486-492.

23. LICHTENTHALER, H.K.; AČ, A.; MAREK, M.V.; KALINA, J.; URBAN, O. 2007. Differences in pigment composition, photosynthetic rates and chlorophyll fluorescence images of sun and shade leaves of four tree species. Plant Physiol. Bioch. 45:577-588.

24. LICHTENTHALER, H.; WELLBURN, A. 1983. Determination of total carotenoids and chlorophyll $a$ and $b$ of leaf extract in different solvents. Biochem. Soc. Trans. 603:591-592.

25. MURCHIE, E.H.; HORTON, P. 1998. Contrasting patterns of photosynthetic acclimation to the light environment are dependent on the differential expression of the responses to altered irradiance and spectral quality. Plant Cell Environ. 21:139-148.

26. NAUMBURG, E.; ELLSWORTH, D.S. 2000. Photosynthesis sunfleck utilization potential of understory saplings growing elevated $\mathrm{CO}_{2}$ in FACE. Oecologia. 122:163-174.

27. PAOLINI, J.; BARBONI, T.; DESJOBERT, J.M.; DJABOU, N.; MUSELLI, A.; COSTA, J. 2010. Chemical composition, intraspecies variation and seasonal variation in essential oils of Calendula arvensis $\mathrm{L}$. Biochem. Syst. Ecol. 38:865-874.

28. PATRICK, K.F.M.; KUMAR, S.; EDWARDSON, P.A.D.; HUTCHINSON, J.J. 1996. Induction of vascularization by an aqueous extract of the flowers of Calendula officinalis L. the European marigold. Phytomedicine. 3(1):11-18. 
29. PERCIVAL, G.C. 2004. Evaluation of physiological tests as predictors of young tree establishment and growth. J. Arboric. 30(2):80-92.

30. PERI, P.L.; MOOT, D.J.; JARVIS, P.; MCNEIL, D.L.; LUCAS, R.J. 2007. Morphological, anatomical and physiological changes of orchard grass leaves grown under fluctuating light regimes. Agron. J. 99:15021513.

31. POMPELLI, M.F.; MARTINS, S.C.; ANTUNES, W.C.; CHAVES, A.R.; DaMATTA, F.M. 2010. Photosynthesis and photoprotection in coffee leaves is affected by nitrogen and light availabilities in winter conditions. J Plant Physiol. 167(13): 1052-1060. doi: 10.1016/j. jplph.2010.03.001.

32. RALPHS, M.H.; MANNERS, G.D.; GARDNER, D.R. 1998. Influence of light and photosynthesis on alkaloid concentration in larkspur. J. Chem. Ecol. 24:167182.

33. RAMANAN, C.; GRUBER J.M.; MALÝ, P.; NEGRETTI, M.; NOVODEREZHKIN, V.; KRÜGER, T.P.; MANČAL, T.; CROCE, R.; VAN GRONDELLE, R. 2015. The role of exciton delocalization in the major photosynthetic light-harvesting antenna of plants. Biophys J. 108(5): 1047-1056. doi: 10.1016/j.bpj.2015.01.019.

34. ROSEVEAR, M.J.; YOUNG, A.J.; JOHNSON, G.N. 2001. Growth conditions are more important than species origin in determining leaf pigment content of British plant species. Funct. Ecol. 15:474-480.

35. SARIJEVA, G.; KNAPP, M.; LICHTENTHALER, H.K. 2007. Differences in photosynthetic activity, chlorophyll and carotenoid levels, and in chlorophyll fluorescence parameters in green sun and shade leaves of Ginkgo and Fagus. J. Plant Physiol. 164(7):950-955.

36. SENEVIRATHNA, A.M.W.K.; STIRLING, C.M.; RODRIGO, V.H.L. 2003. Growth, photosynthetic performance and shade adaptation of rubber (Hevea brasiliensis) grown in natural shade. Tree Physiol. 23:705-712.

37. TEZARA, W.; MARTÍNEZ, D.; RENGIFO, E.; HERRERA, A. 2003. Photosynthetic responses of the tropical spiny shrub Lycium nodosum (Solanaceae) to drought, soil salinity and saline spray. Ann. Bot.Lond. 92:757-765.

38. VANDENBUSSCHE, F.; PIERIK, R.; MILLENAAR, F.F.; VOESENEK, L.A.C.J.; VAN DER STRAETEN, D. 2005. Reaching out of the shade. Curr. Opin. Plant Biol. 8:462-468.

39. YAMAZAKI, J.; TAKAHISA, S.; EMIKO, M.; YASUMARO, K. 2005. The stoichiometry and antenna size of the two photosystems in marine green algae, Bryopsis maxima and Ulva pertusa, in relation to the light environment of their natural habitat. J. Exp. Bot. 56 (416): 1517-1523.

40. ZHANG, S.; MA, K.; CHEN, L. 2003. Response of photosynthetic plasticity of Paeonia suffruticosa to changed light environments. Environ. Exp. Bot. 49:121-133.

Received: 23 August 2014

Accepted: 25 March 2015

How to cite (Cómo citar):

Casierra-Posada, F.; Ávila-León, O.F. 2015. Shade tolerance of marigold plants (Calendula officinalis). Rev. U.D.C.A Act. \& Div. Cient. 18(1): 119-126. 